\title{
WHAT LIES BEHIND A PLEURISY?
}

\author{
Mihaela Anton ${ }^{1}$, Theodora Militaru², Denise-Ani Mardale², Roxana Diaconu², \\ Camelia Maximeasa ${ }^{1}$, Florina Vasilescu², Cezar Bețianu², Ioana Ștefănescu², \\ Ruxandra Jurcut, ${ }^{1}$, Ciprian Jurcut $t^{2}$ \\ 1. Cardiology Clinic, "PhD C.C. Iliescu" Emergency Institute for Cardiovascular Diseases, \\ Bucharest, Romania \\ 2. Medical Clinic 2, Central Military Emergency University Hospital "Dr. Carol Davila", \\ Bucharest, Romania
}

\begin{abstract}
Erdheim-Chester syndrome, a non-Langerhans histiocytosis, is a very rare disease, in the present approximately 500 cases being reported in literature. It is characterized by the histiocytic infiltration of various organs and systems, therefore clinical signs and symptoms are miscellaneous. Despite that, there are a few patognomonic elements that help recognizing the disease: symmetrical involvement in the long bones of the lower limbs, bilateral perirenal infiltration ("hairy kidneys") and circumferential aortic infiltration ("coated aorta"). However, in order to confirm the diagnosis, biopsy is required, histopathologic examination revealing "foamy" histiocytes. Currently, interferon alpha serves as the first line of treatment, most literature data showing that it might improve survival rate in patients diagnosed with Erdheim-Chester syndrome.
\end{abstract}

Keywords: Erdheim-Chester syndrome, pleurisy, dyspnea

\section{Rezumat}

Sindromul Erdheim-Chester, o histiocitoză cu celule non-Langerhans, este o boală extrem de rară, până la acest moment fiind raportate în literatură aproximativ 500 de cazuri. Este caracterizat prin infiltrarea cu macrofage a diferitelor organe și sisteme, motiv pentru care manifestările clinice sunt extrem de variate. Cu toate acestea, este definit prin anumite elemente imagistice patognomonice: afectarea simetrică a oaselor lungi de la nivelul membrelor inferioare, infiltrarea perirenală bilaterală ("hairy kidneys") și periaortică circumferențială ("coated aorta"). Pentru confirmarea diagnosticului, însă, este nevoie de biopsie, examenul histopatologic evidențiind macrofage "spumoase". In prezent, tratamentul de primă linie este cu interferon alfa, datele din literatură aratând că acesta ar îmbunătăți rata de supraviețuire a pacienților diagnosticați cu sindrom Erdheim-Chester.

Cuvinte cheie: sindrom Erdheim-Chester, pleurezie, dispnee 


\section{INTERNAL}

\section{Clinical cases}

\section{Case presentation}

We report the case of a 69-year-old man, experiencing dyspnea with moderate effort, a symptomatology that began 3 months earlier, after an infectious respiratory episode. From his personal pathological history, we can mention: essential hypertension of stage III with additional high risk, endarterectomy in the right common carotid artery and obliterated lower limb arteriopathy of stage IIA Leriche Fontaine.

Clinically, we noted reduced basal breath sounds on the right, SO2 95\%, HBP 140/80 $\mathrm{mmHg}, 80 \mathrm{bpm}$, rhythmic heart sounds, with no breaths, absent peripheral pulse, at the level of the posterior tibia and bilateral pedis arteries.

Biologically, we notice biological inflammatory syndrome and nitrogen retention (FRG $49.7 \mathrm{ml} / \mathrm{min} / 1.73 \mathrm{~m} 2$ ). The usual immunology was negative (ANA, antiADNdc, antiRNP, antiRo, antiLa, anti SCL70, anticentromer, antijo1, FR, antiCCP), and the tumour markers were normal.

Heart-lung x-ray reveals pleural effusion.

Echocardiography shows normal sized cavities, LVEF $50 \%$ through segmental dysfunction in the inferior region, visceral pericardial thickening (anterior to RV $5 \mathrm{~mm}$ posterior to LV $13 \mathrm{~mm}$ ) and a fine blade of pericardial fluid. We also notice a dense material at the level of the abdominal aorta walls, which attracted particular attention, In order to assess the severity of respiratory dysfunction, spirometry was performed emphasizing moderate mixed respiratory dysfunction with a $37 \%$ vital capacity decrease and $45.6 \%$ maximum expiratory volume per second from the predicted value. At the same time, in an attempt to identify the etiology of pleural effusion, bronchoscopy was performed. It showed a normal appearance, with the presence of serum mucous secretion in small amount, while bronchial aspirate was negative for bacterial flora, fungus, or acid-alcohol resistant bacillus.

Thoracentesis was also performed with pleural fluid sampling, which turned out to be transudated, with a normal LDH value and a negative Rivalta reaction. Testing for atypical cells was all negative, and their culture was sterile.

Within the diagnosis, abdominal ultrasound was also performed, being observed a dense bilateral perirenal mass. For this reason, for better assessment, it was decided to continue the investigation with a thoracicabdominal computer tomography observing the presence of a right pleural effusion with pleural thickening and pericardial effusion in small quantity. We note the presence of a dense perioaortic and perirenal bilateral material and a right cleroatrophic kidney. This highly suggestive image raised 


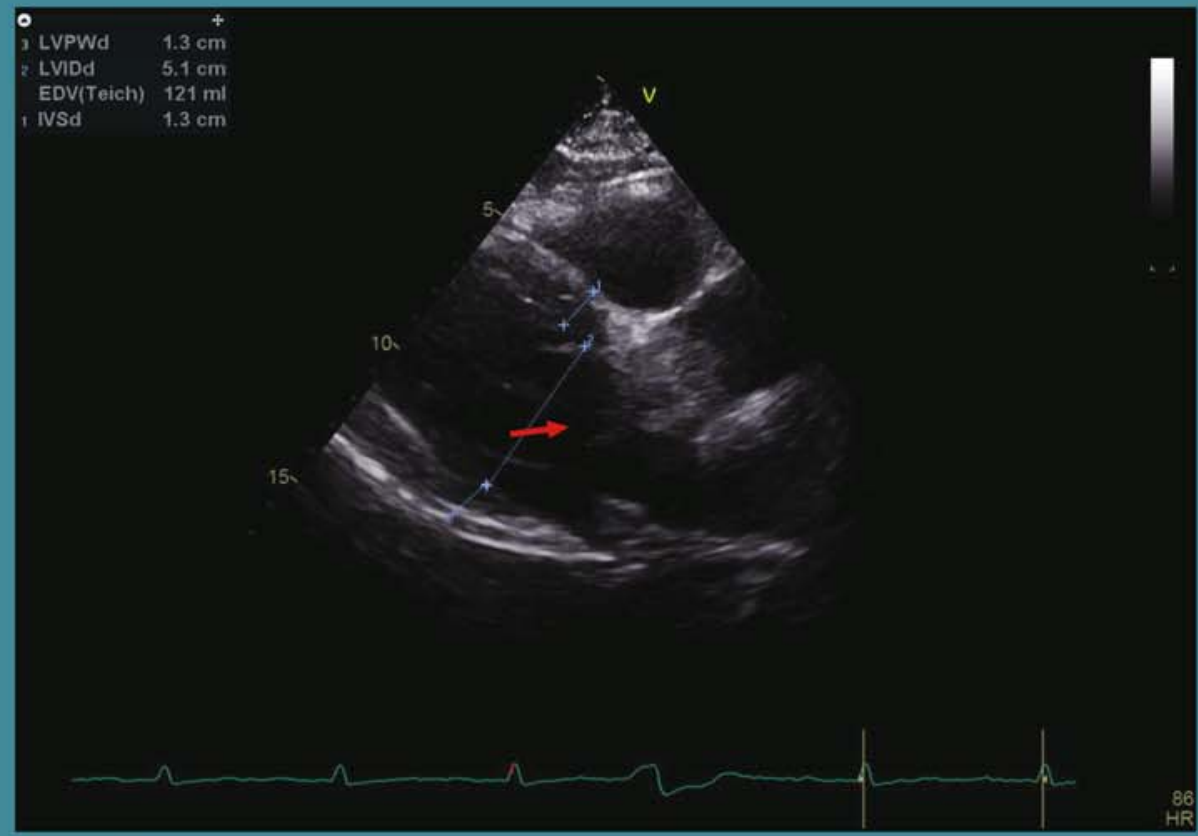

Figure 1.

Echocardiography, parasternal long axis section - normal-sized cardiac cavities,

posterior to thickened pericardium of $L V$

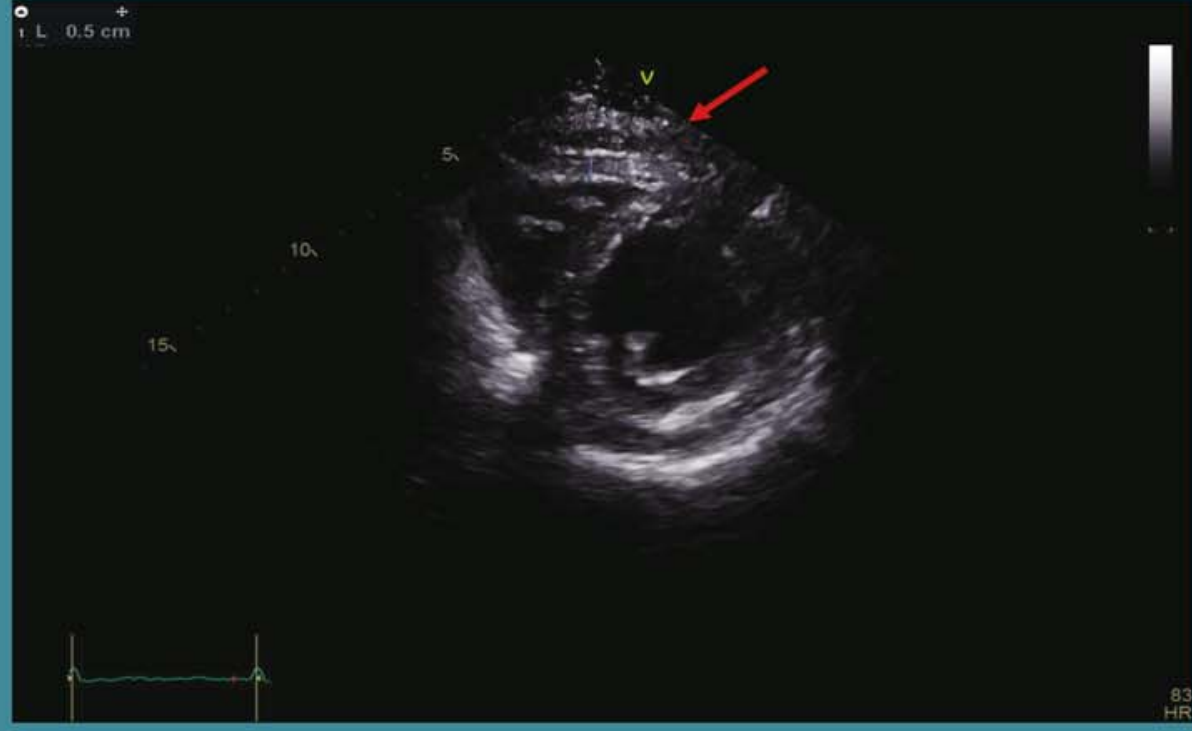

i. $2.5 . \mathrm{cm}^{+}$

Figure 2.

Echocardiography, parasternal short axis section - fine blade of fluid above RV and pericardium thickening at this level

Figure 3.

Echocardiography, subcostal section, abdominal aorta level dense periaortic material 


\section{INTERNAI}

\section{Clinical cases}

suspicion of Erdheim-Chester syndrome. In order to assess the bone impairment in the disease, bone scintigraphy was performed, with the identification of an increased uptake in the distal epiphysis of the femur and the proximal portion of the tibia, bilateral, symmetrical uptake, elements which are extremely suggestive of Erdheim-Chester syndrome.

\section{Skeleton: Long bones osteosclerosis (bone pain)}

Cranium \& CNS:

Pituitary defects (diabetes insipidus, panhypopituitirism)

Retro-orbital lesions (exophthalmos)

Cerebellar lesions (ataxia)

Cardiovascular:

Pericardial infiltration / effusion

Periaortic sheathing ("coated aorta")

Myocardial infiltration / right atrial tumor

Pulmonary:

Interstitial lung disease

Pleural effusion

Renal \& Retroperitoneal:

Perirenal infiltration ("hairy kidney")

Post renal obstruction (hydronephrosis)

Renal artery stenosis (renovascular hypertension)

Cutaneous: Periorbital xanthelasmae Erdheim-Chester syndrome

(R. Mazor, M. Mazor, Y. Shoenfeld-Erdheim- Chester Disease a comprehensive review of the literature, Orphanet Journal of Rare Diseases, 2013, 8:137)
To confirm the diagnosis, a biopsy puncture was performed from the perirenal tissue, histopathological examination identifying fibroconjunctival tissue, frequent histiocytes, rare lymphocytes and plasmocytes, aspect that is also consistent with the diagnosis of Erdheim-Chester syndrome.

In the table below, the main clinical presentations of Erdheim-Chester syndrome described in the literature are depicted schematically.

Therefore, we note that a large part of them are present in the case of our patient:

- bone impairment

- pericardial and periaortic infiltration

- presence of pleural effusion

- bilateral perirenal infiltration

Impairment of the central nervous system was evaluated through a brain computer tomography, but no pathological elements were identified. Thus, based on these clinical and imaging elements and the histopathological examination of the perirenal tissue the diagnosis of Erdheim-Chester syndrome is established. The patient was referred to the Haematology Department to initiate treatment and subsequent follow-up.

\section{Discussions}

Erdheim-Chester syndrome is a rare disease, a non-Langerhans histiocytosis. ErdheimChester syndrome, which was first described in 


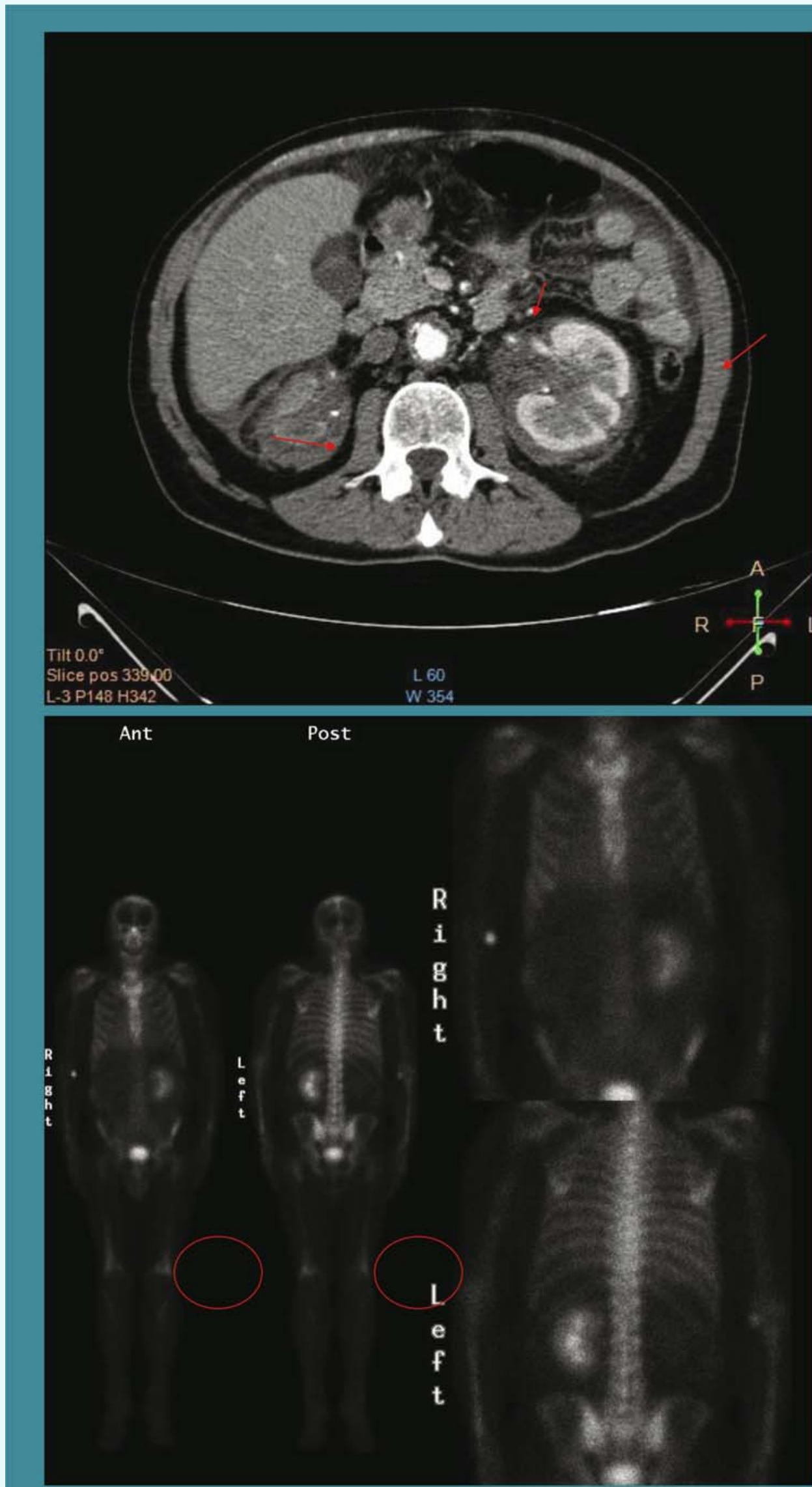

Figure 4. Abdominal CT scan, axial section densification at perirenal and periaortic level, right cleroatrophic kidney.

Figure 5. Bone scintigraphy Increased uptake in the distal femur epiphiseal and bilateral tibia proximal area 


\section{INTERNAL}

Clinical cases

1930 , is a very rare disease, in the present approximately 500 cases being reported in literature. It is a non-Langerhans cell histiocytosis, characterised by histiocytes infiltration in different organs or systems, most often described in patients aged 40 to 70 years, with a slight predominance in male gender. The pathophysiological mechanisms that lie behind the emergence of the disease are still incomplete, the data known so far suggesting a possible involvement of a BRAF v600 gene mutations. Because histiocytes infiltration can affect any organ or system, clinical presentations can be extremely varied, and the diagnosis can be difficult to establish. However, there are a few pathognomonic elements for this syndrome:

- bilateral symmetrical impairment of the long bones of the lower limbs (often at the level of the distal portion of the femur and proximal portion of the tibia)

- bilateral perirenal infiltration ("hairy kidneys")

- circumferential periaortic infiltration ("coated aorta")

However, in order to confirm the diagnosis, biopsy is required, histopathologic examination revealing "foamy" histiocytes. Regarding the treatment, there is no consensus so far. Most literature data show that treatment with interferon alpha would improve the survival rate of patients diagnosed with Erdheim-Chester syndrome.

\section{Conclusions}

Through the presentation of this case, we would like to point out that complex pathologies can lie behind common symptoms, Erdheim-Chester syndrome being a syndrome rarely encountered in daily practice, but it deserves to be considered.

\section{Bibliography}

1. R. Mazor, M. Mazor, Y. Shoenfeld et al- ErdheimChester Disease a comprehensive review of the literature, Orphanet Journal of Rare Diseases, 2013, 8:137

2. B. Boxrud, C. Esmaeli, B.Kurzrock et al- Successful treatment of Erdheim-Chester disease, a non-Langerhanscell histiocytosis, with interferon-alpha. Blood 2005, 106:2992-2994

3. J. Haroche, L. Arnaud, Z. Amoura et al- ErdheimChester disease. Curr Opin Rheumatol 2012, 24:53-59

4. L. Arnaud L, P. Beigelman-Aubry, C. Capron et alPulmonary involvement in Erdheim-Chester disease: a single-center study of thirty-four patients and a review of the literature. Arthritis Rheum 2010, 62:3504-3512.

5. H. Hemmelder, MH. de Graaf, W, Grond et al Scintigraphic diagnosis of Erdheim-Chester disease. J Clin Oncol 2011, 29:e470-472.

6. M. Alharthi, A. Calleja, P. Panse et al - Multimodality imaging showing complete cardiovascular involvement by Erdheim-Chester disease. Eur J Echocardiogr 2010, 11:E25.

7. J. Serratrice, B. Granel, C. De Roux et al "Coated aorta": a new sign of Erdheim-Chester disease, J Rheumatol 2000, 27:1550-1553. 